\title{
THE CONTRIBUTION OF UNDERSTANDING ROLE AND EXPECTATION ROLE RELATED TO MIDLE MANAGEMENT PERFORMANCE ACHIEVEMENT BASED ON TEN LEADERSHIP ROLE BY MINTZBERG
}

\author{
Muhammad Hidayat \\ PPs Magister manajemen STIE Nobel Indonesia \\ Email : hidayat@stienobel-indonesia.ac.id
}

\begin{abstract}
This research is to analyze whether there is a link between understanding role and expectation role related to midle management performance achievement. The method used in this research is descriptive analytic method using quantitative approaches. Analytical tools used by the writer is statistical analysis, this tool function is to examine the different average through paired samples $t$-test and also using rank Spearman's correlation analytic. The result of paired samples t-test research analytic is to prove that there is a significant difference between midle management understanding role and expectation role center leader based on ten leadership role written by Mintzberg. The correlation analytic by Rank Spearman 's correlation analysis prove that there is thigh and significant link between understanding role based on ten leadership role written by Mintzberg among branch leader work achievement.
\end{abstract}

Keyword: "LeadershipRole, Mintzberg Model"

\section{INTRODUCTION}

This research aimed to analyze and investigate the relationship between the understanding role and expectations role related to the performance of the branch leadership, which is critical for understanding the role of the company in accordance with the hope of realizing its vision and mission.

The rapid development of science and management especialy on human resources management has greatly contributed to the company's desire to have human resources who are able to actualize themselves in terms of their role in the organization. The demands in which every individual in an organization should have the same view with the management for the role that is given, become an important requirement. Role is an important term in the context of organization. A role is a set of connected behaviour right obligations beleifs and norm as conceptualized. Kumar. et al. (2013). Role expectation has been defined in term of prescription and 


\section{Jurnal Mirai Management Terakreditasi Nasional}

e-ISSN : 2597 - 4084, Volume 4 No.1 2019

Available Online at: https://journal.stieamkop.ac.id/index.php/mirai

proscription held by the member of the counter position of the role it is the expected behaviour of the role incumbent. Sanghi S. (2011).

Good understanding of the role will give a great effect and influence the quality of ones task completion, and conversely the lack of the role will deliver the work that does not comply with the expectations given by the organizations, an understanding of the roles can affect a person's performance achievement. The performance of employee in an organization depend largely on expectation set for them it also reflect on the effectivenes of leadership in the organization. The manager plays a key role in setting the subordinate's expectations and helping achieve their goals if the manager's expectations are high. Performance and productivity automaticaly go up is also posible if expectation are low then there is a drop in performance. Ozcan (2016). Based on research by Yuan and Woodman in 2017 his stated that employees in a company engage in innovative behaviors because they are motivated by their expectations for achieving good performance. Innovative behavior is based on a good understanding of the role it has in working.

Management of a company consists of three levels, top management, middle management and lower management, from these three levels of management the middle management level is the most unique one, basically the medium management level, in action will serve as a liaison between the other two levels of management; upper management and lower-level management. Midle management are betwen two organizational level the top management and the first line manager and employee. They are expected to enhance organizational performance and to lead their subordinate to top performance. Korpela (2014). But in other view Haneberg (2005) about the midle management posistion said that midle management have a poor reputation sometime being seen as ineffective organizational barriers although they are the ones with pottentioal to reduce inefficiency and problem and have the greatest influence on strategic performance.

The complexity of the role of middle management is something interesting to be analyzed for their effectiveness. It will determine the success of the organization in achieving its goals. For these vital roles, middle management should be given to someone who understands very well the role to which it aspires for, without good understanding the original purpose of the company, is very likely the plan will run not according to a predetermined plan before.

Based on the above statement, this research aims to determine the extent to which an understanding of the role of middle leaders and the role they played. As a consideration that can provide accurate results, in this research selected a business group that has many branches spread in various regions.

In the Group business that has many branches, operations are practically at the middle management level that are concentrated on branches, Basically, the expectation of company that have many branches to the branch chief are on the ways in implementing the strategy and in the right and quickly decision-making that 


\section{Jurnal Mirai Management Terakreditasi Nasional}

e-ISSN : 2597 - 4084, Volume 4 No.1 2019

Available Online at: https://journal.stieamkop.ac.id/index.php/mirai

is associated with the high intensity of the economy development as well as the influence of social and cultural aspect in different regions.

Demands for suitability to the role of middle management to communicate various strategic policy from above, as well as gather information about the various operational issues as factual information that is useful to management in decisionmaking is an absolute must, in this case be a matter of understanding the role can not be ignored.

Neglecting these demands will increase the likelihood of the stakeholders, in this case the middle management does not know clearly and precisely what has been expected by his superiors or the company. If this happens then it is possible for employers will easily give the low value of the work performance of the holders of these roles. Middle management level is required to implement the strategy of the company and translate them in operational activities, in addition they are also required to provide accurate information relating to operational issues in the field.

Middle management should be able to act as a symbol of the company that will be a representation of the company in operational issues. Middle management should be able to become a leader in the management level to which it aspires and to be a liaison between the company's interests with the interests of operations.

With regard to the interests of the company to determine whether the company's vision and mission can be applied and then translated operationally middle management should also serve as monitor system for the implementation of programs and systems which the company is spearheading the operations that can be used as a measure of execution of such expectations.

The roles are more detailed as the successor to the role of information, the role of spokesman for the role of entrepreneurial, role of handling the disorder, the role of human resource allocation and the role of the negotiator should be held by management components including mid-level management.

\section{LITERATURE STUDY}

\section{The Importance of Midle Management Position}

Middle-level management is the most vital management level because this level will be a process for the transformation and policy decisions of the company's strategy. Which is at that level will be a process transformation from the formulation phase to the implementation phase. Korpela (2014), Haneberg (2005) Seegers (2012). Company have the absolute importance that duty bearers at this level may have a sensitivity to the companies direction and purpose especially in the implementation phase of the strategy that is quite crucial. Thus an understanding of the role become companies demand to be owned by every individual in the organization is no exception for the stakeholders at the middle management level. 


\section{Jurnal Mirai Management Terakreditasi Nasional}

e-ISSN : 2597 - 4084, Volume 4 No.1 2019

Available Online at: https://journal.stieamkop.ac.id/index.php/mirai

Clarity of roles to be a very influential factor in understanding the role. In this case between role clarity and understanding of the role strongly associated with problems of perception of the stakeholders. Hastuti (1987) states that "the perception of the role is a degree of understanding of the role of stakeholders, so that the behavior in question knows what to display and how to display it in question. Davis (1972) said that the activities of the leaders or workers depending on their perception of their role. They know the behavior that should be displayed on the situation.

According to Allanse and Fleet cited by Hastuti (1987) states that in the role process will be possibility occur differences in the understanding of the role; thus behavior, the expected role and the understand of the role will determine someone perception than this perception will determine the achievement beside the skills possessed and cultivated of himself.

\section{Management Role}

Infact the company has high expectation for its human resources. Mintzberg (1989) stated that the human resources roles could be categorized into three forms, namely: the interpersonal roles, informational roles and the roles of decision-making.

Mintzberg cited by Setiawan (2017) explain Interpersonal roles can be seen from the three forms of role, firstly the role as a symbol of the organization's existence. The role was played in a variety of activities that are legal and ceremonial. Second: As the leader this role functions is to responsible in motivate and provide direction to subordinates which in reality means "dealing" with all subordinates. The third role is liaison role, this role is the ability of the leader to create extensive network with special attention to those who are able to do something for the organization as well as the various parties have the necessary information by the organization. Informational roles can be seen from three forms of role, the first is the role of transmitter of information, a leader always receives information from inside and outside the organization, even the information was not to be addressed to him, but to others in the organization. In this case it should be noted that a leader must pass the information accurately and quickly. Second roles as desimenator information. The information received by a person, may be useful for carrying out the functions of organization, but sometimes distributed to the other person or others in the organization. This role requires deep understanding of the meaning of the received information and the knowledge of the various functions to be held. The third role is an organization spokesman role the person as a chief must provide information accurately to others needs, of course, the information must be in line with what the line of policy and strategy.

The roles of decision can be devided into four types, first as a entrepreneur role, leader should be able to continuously assess the situation faced by the 


\section{Jurnal Mirai Management Terakreditasi Nasional}

e-ISSN : 2597 - 4084, Volume 4 No.1 2019

Available Online at: https://journal.stieamkop.ac.id/index.php/mirai

organization in order to seek and find opportunities that can be exploited, although these activities often require a change in the organization. second as a shock disorder roles, this role means a willingness to take responsibility for taking corrective action when organization faces a serious disorder, which is if the problems ca not be handle or been resolved it will deal with the negative impact on the organization. Third resource divider role, this role is related to the authority of a leader who is a stakeholder authority to allocate funds and resources owned by the company to produce products or services as well as other operational problems. The fourth is a role as a negotiator for the organization, the higher one's position more and more he interacts with various parties outside the organization than with people inside. In other words, he is more often served as a negotiator for the organization means that a person who is believed to hold office are required to have the ability to identify influential factors for the success of the organization, identify constraints as well as opportunities that may appear suddenly and unforeseen threats.

The company has an interest in the ability of its resources that interest is reflected in his decision to give authority and responsibility to elect the resources to be able to carry out its role as expected by the company thus measure the performance of these resources depends on whether they can understand the appropriate role with the expectations given to them from the company. From this problems it is necessary to do a research of whether the oeganizations individual can understand the role appropriate with the expectations role given to them.

\section{Performance Achievement}

Kreitner (2003) put forward in an attempt to predict achievement "Achievement is determined by more than just efort. Achievement depends on the employees ability and character as well as their perception toward the role." This means that employees with high ability will be able to maintain high achievement with a certain level of effort than the other.

Lawler and Porter (1967) is more sharply stated that job performance is a person's success in implementing their role. From the above stetements it is clear that the performance achievement depends on how deeply the person understand their role and their responsibilities. Therefore it is necesasary for company to give information in details about the organizational roles toward every level of management as expectation. The relation betwen performance achievement result with expectation Ozcan (2016) said that the performance of employee in an organization depends largely to the management expectation to the employee.

Research to analyze the understanding of the role and expectations of the role performed by Hastuti (1987) this research proved that there are differences in the perception and acceptance of the role of role expectations that affect job performance. The research was conducted at PT Industri Pesawat terbang 


\section{Jurnal Mirai Management Terakreditasi Nasional}

e-ISSN : 2597 - 4084, Volume 4 No.1 2019

Available Online at: https://journal.stieamkop.ac.id/index.php/mirai

nusantara (IPTN) which at the moment is a prestigious company and employ workers who have the intellectual prowess with the results of the research was intended to prove again whether there are differences in the roles of other companies that have operational scale that is different from the human resources differently.

Based on the arguments above the hypothesis of this study is arranged as follows

Based on the arguments above, the hypothesis of this study is arranged as follows;

H1 There is a difference between expectations and understanding roles.

The expectation role is a normative demand from the leader to his subordinates to carry out the obligations that become his responsibility while understanding the role is the perception by the stakeholders for the role they have. In some cases someone thinks about what to do based on certain considerations. One of that, is the consideration of the benefits and convenience of someone to do or not do something, as stated by Ajzen quoted by Jogiyanto (2007), this opinion was also conveyed by Razak (2010) thus, it becomes a strong reason if there is an influence between expectations and understanding roles, that comes from two different groups.

H2 There is a relationship between understanding the role and Job Performance When a person understands the role carried, he will result a good task implementation because the work or task performed, will be carried out in accordance with the correct rules. That originate from the proper understanding of these responsibilities (Kreitner, 2003); (Rosali and Jogi, 2015)

\section{RESEARCH DESIGN AND METHODOLOGY}

\section{Sample}

The population in this study are all employees who are in the middle management position. They are taken from a well-known multi-national company in South Sulawesi, namely PT Bosowa Propertindo. The company itself was chosen as an object to see the extent of the middle management to understanding the role, the top management hopes for several reasons, they are (1) PT BosowaPropertindo is a business group that has several business units such as real estate, commercial buildings, hotels, the hospital and contracting business group company are under the Bosowa Corporatin. It is as one of the well-known group company in eastern of Indonesia. (2) The property business group is the most dynamic business group among other business groups. (3) In general, the property industry is one of the leading national industries. Considering to the limited population, the sampling technique uses census sampling, where the entire population of 60 people in the middle management position, are taken as the sample in this study. The questionnaire are consisted of two form, the first questionnaire was given to the top 


\section{Jurnal Mirai Management Terakreditasi Nasional}

e-ISSN : 2597 - 4084, Volume 4 No.1 2019

Available Online at: https://journal.stieamkop.ac.id/index.php/mirai

management to represent the company to state the extent of the expectations the role of the company to middle management as seen from 10 leadership characteristics according to Mintzberg. The second questionnaire was given to the middle management to state the extent of understanding the role, measured through 10 leaderships according to mintzberg. The third questionnaire is to determine the level of performance of the middle management.

\section{Measurement}

The data in this study were taken from questionnaires. By filling questionnaires using a Likert scale 1-5 (Strongly disagree - Strongly Agree), such as the measurements used in the study. The data analysis of research results was carried out through several stages. The first stage was to find out the quality of the data by conducting a reliability test and testing the validity. The second stage was by conducting data analysis to compare them through the average difference test from the results of the questionnaire given to different groups of respondents. The third stage was to compare the relationship between the understanding the role to performance and the fourth stage was to stage of testing the research hypothesis.

Table 1: Measurement of Variable

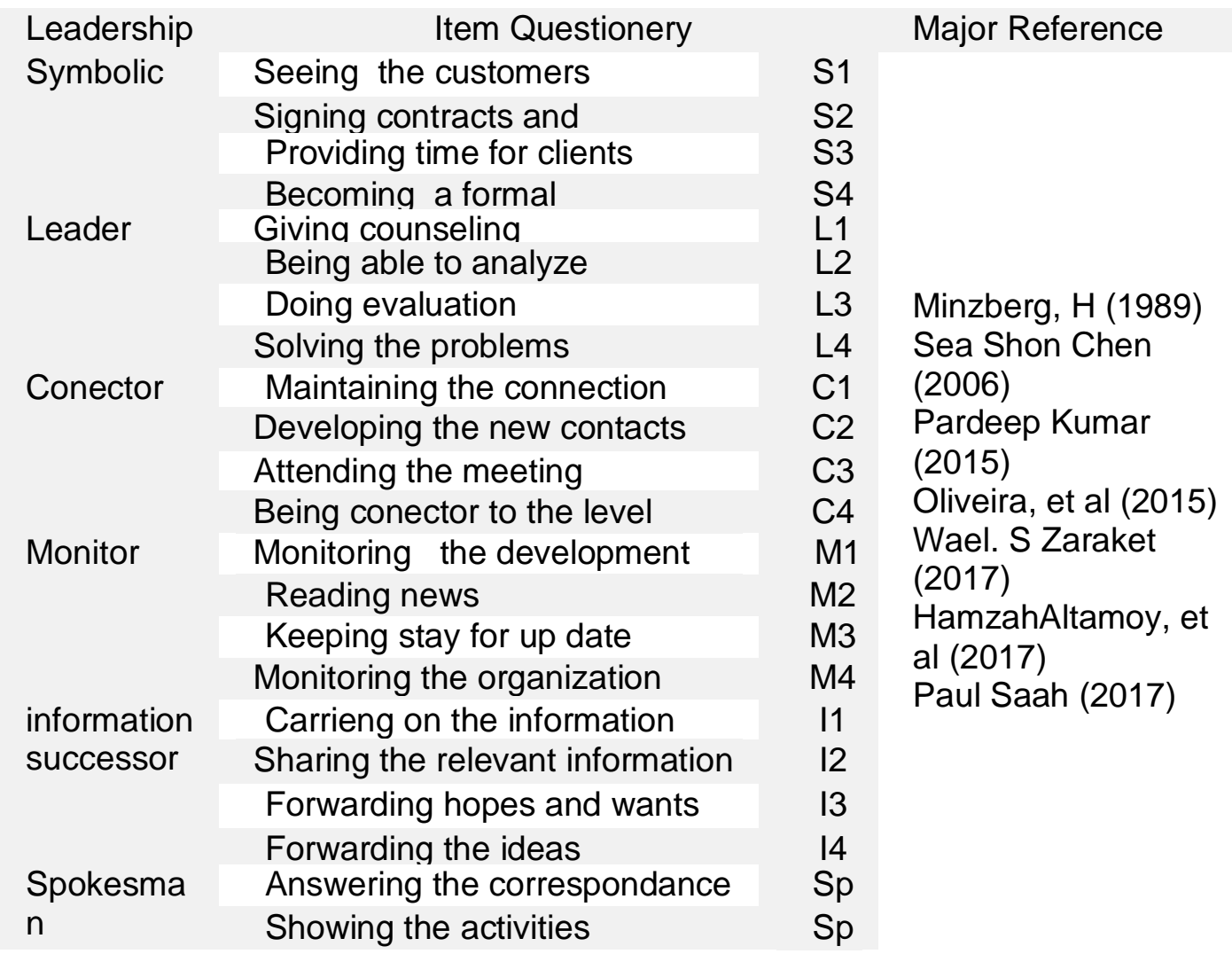




\section{Jurnal Mirai Management Terakreditasi Nasional}

e-ISSN : 2597 - 4084, Volume 4 No.1 2019

Available Online at: https://journal.stieamkop.ac.id/index.php/mirai

\begin{tabular}{|c|c|c|c|}
\hline \multirow{5}{*}{$\begin{array}{l}\text { Entreprene } \\
\text { urial }\end{array}$} & Explaining the problems & Sp & \multirow{18}{*}{$\begin{array}{l}\text { Minzberg, H (1989) } \\
\text { Sea Shon Chen } \\
\text { (2006) } \\
\text { Pardeep Kumar } \\
\text { (2015) } \\
\text { Oliveira, et al (2015) } \\
\text { Wael. S Zaraket } \\
\text { (2017) } \\
\text { HamzahAltamoy, et } \\
\text { al (2017) } \\
\text { Paul Saah (2017) }\end{array}$} \\
\hline & Making clarification to an & Sp & \\
\hline & Evaluating the output & E1 & \\
\hline & Making continously & E2 & \\
\hline & Finding the effective method & E3 & \\
\hline \multirow{4}{*}{$\begin{array}{l}\text { Troublesho } \\
\text { oting }\end{array}$} & Making development effort & E4 & \\
\hline & Making immediatly action & T1 & \\
\hline & Handling the complaint & $\mathrm{T} 2$ & \\
\hline & Supervising the program & T3 & \\
\hline \multirow{4}{*}{$\begin{array}{l}\text { Resources } \\
\text { Allocation }\end{array}$} & Handling the dispute & T4 & \\
\hline & Involving in making plans & R1 & \\
\hline & Distributing the resources & $\mathrm{R} 2$ & \\
\hline & Delegating the authority & R3 & \\
\hline \multirow{5}{*}{$\begin{array}{l}\text { Negosiator } \\
\text { S }\end{array}$} & Otority & R4 & \\
\hline & Making internal negosiation & N1 & \\
\hline & Making external negosiation & N2 & \\
\hline & Solving the problems & N3 & \\
\hline & Making Official ly negosiation & N4 & \\
\hline
\end{tabular}

Model and Technical Data analysis

This research used statistical techniques analysis by performing testing via t-test analysis as follows:

Different average $t$ test for interconnected samples (paired sample test)

$$
t=\frac{\sum D}{\sqrt{\frac{\left(N \sum D^{2}-\left(\sum D\right)^{2}\right.}{N-1}}}
$$

Where :

$$
\begin{aligned}
& \sum d i^{2}=\text { The amount of the difference of the two samples were } \\
& \text { measured by the formula: } \\
& \Sigma D=\left(X_{1}-X_{2}\right)
\end{aligned}
$$

Rank Spearman correlation analysis 


\section{Jurnal Mirai Management Terakreditasi Nasional}

e-ISSN : 2597 - 4084, Volume 4 No.1 2019

Available Online at: https://journal.stieamkop.ac.id/index.php/mirai

$$
\rho=1-\frac{6 \sum d t^{2}}{n\left(n^{2}-1\right)}
$$

Where :

$$
\begin{array}{ll}
\rho & =\text { korelasi rank Spearman's Coeficien (rho) } \\
\sum d i^{2} & =\text { Number of difference squares between two variables } \\
n & =\text { Number of samples }
\end{array}
$$

To facilitate the data processing was used SPSS (Statistical Package for Social Sciences) statistical program application.

\section{RESULTS}

The results of data analysis using SPSS statistical applications as shown in Table I shows there is a difference in perception between the branch leader of their understanding role with central management expectations role.

Tabel 1

Paired Sample t-test to determine whether there is a difference of perception betwen understanding role and expectations role.

$\begin{array}{clcccc}\text { No } & \text { Role } & \begin{array}{c}\text { Branch leader } \\ \text { Understandin } \\ \text { g average }\end{array} & \begin{array}{c}\text { Central } \\ \text { leader } \\ \text { Understandi } \\ \text { ng average }\end{array} & \text { t } & \text { Sig } \\ \mathbf{1} & \text { Symbolic } & 15,43 & 16,67 & -4,085 & 0,0 \\ \mathbf{2} & \text { Leader } & 29,80 & 36,43 & - & 0,0 \\ \mathbf{3} & \text { Conector } & 14,43 & 19,93 & - & 0,0 \\ \mathbf{4} & \text { Monitor } & 19,47 & 34,03 & - & 0,0 \\ \mathbf{5} & \text { information } & 17,05 & 28,50 & - & 0,0 \\ \mathbf{6} & \text { Spokesman } & 13,43 & 23,07 & - & 0,0 \\ \mathbf{7} & \text { Entrepreneurial } & 14,43 & 20,40 & - & 0,0 \\ \mathbf{8} & \text { Troubleshooting } & 22,72 & 26,47 & -7,863 & 0,0 \\ \mathbf{9} & \text { Resources } & 32,58 & 35,27 & -5,056 & 0,0 \\ \mathbf{1 0} & \text { Negosiators } & 12,97 & 25,00 & - & 0,0\end{array}$

From the above data it can be analyzed as follows:

1. Through quantitative calculation of the ten leadership role (symbolic, leader, liaison, monitor, router information, spokesperson, entrepreneur, disturbance handling, resource allocation and negotiators) were analyzed in this research, showed a significant difference between the understanding of the role of the branch leadership on ten leadership 


\section{Jurnal Mirai Management Terakreditasi Nasional}

e-ISSN : 2597 - 4084, Volume 4 No.1 2019

Available Online at: https://journal.stieamkop.ac.id/index.php/mirai

role, with the expected role from central leadership. The average value of the branch leadership understanding of these roles tend to be lower when compared with the average value expected by the central leadership.

2. The results of the above analysis shows that the employer expects ten leadership role is an important role and should be owned and implemented by the leaders of the branch but the branch leaders allegedly have different perceptions that the largest portion of the leadership role is a role to be performed by the central leadership in this case still looks branch leaders do not understand their role as expected by the central leadership.

3. A qualitative analysis of the respondents in this research indicate the possibility of other causes of these differences, the socialization of the authority and importance of the role of the branch has not done well, so more branch leaders to assume the authority of these roles is in moderate levels.

so from ten leadership role analyzed supports the research hypothesis as shown in Table II, which is all of ten indicators that are entirely reject $\mathrm{Ho}$ and accept $\mathrm{Ha}$ research it's means that there is a significant difference between the understanding role from branch leaders with expectation role of the central leadership of the Group businesses serve as the object of the research.

Table 2

Acceptance and rejection of Research Hypothesis I

\begin{tabular}{cllll} 
No & \multicolumn{1}{c}{ Role } & t.Count & t.Table & $\begin{array}{c}\text { Result } \\
\text { Ho Rejected }\end{array}$ \\
$\mathbf{1}$ & Symbolic & $-4,085$ & 2,000 & Ho Rejected \\
$\mathbf{2}$ & Leader & $-14,771$ & 2,000 & Ho Rejected \\
$\mathbf{3}$ & Conector & $-21,167$ & 2,000 & Ho Rejected \\
$\mathbf{4}$ & Monitor & $-16,549$ & 2,000 & Ho Rejected \\
$\mathbf{5}$ & Information & $-14,508$ & 2,000 & Ho Rejected \\
$\mathbf{6}$ & Spokesman & $-19,433$ & 2,000 & Ho Rejected \\
$\mathbf{7}$ & Entrepreneurial & $-20,230$ & 2,000 & Ho Rejected \\
$\mathbf{8}$ & Troubleshooting & $-7,863$ & 2,000 & Ho Rejected \\
$\mathbf{9}$ & Resources & $-5,056$ & 2,000 & Ho Rejected \\
$\mathbf{1 0}$ & Negosiators & $-26,610$ & 2,000 &
\end{tabular}

Furthermore, as shown in Table 3 there is displayed a strong and significant relationship between the differing perceptions about the role of the branch leader with the expectations of the role from the central management to the branch leaders work performance achievement. 


\section{Jurnal Mirai Management Terakreditasi Nasional}

e-ISSN : 2597 - 4084, Volume 4 No.1 2019

Available Online at: https://journal.stieamkop.ac.id/index.php/mirai

Table 3 Level Of Significancy

\begin{tabular}{clclc} 
No & \multicolumn{1}{c}{ Role } & Correlation & Relationshi & Sig \\
1 & Symbolic & 0,491 & Moderate & 0,000 \\
$\mathbf{2}$ & Leader & 0,409 & Moderate & 0,001 \\
$\mathbf{3}$ & Conector & 0,463 & Moderate & 0,000 \\
$\mathbf{4}$ & Monitor & 0,713 & Strong & 0,000 \\
$\mathbf{5}$ & information successor & 0,516 & Moderate & 0,000 \\
$\mathbf{6}$ & Spokesman & 0,509 & Moderate & 0,000 \\
$\mathbf{7}$ & Entrepreneurial & 0,637 & Strong & 0,000 \\
$\mathbf{8}$ & Troubleshooting & 0,300 & weak & 0,020 \\
$\mathbf{9}$ & Resources Allocation & 0,736 & Strong & 0,000 \\
$\mathbf{1 0}$ & Negosiators & 0,400 & Moderate & 0,002
\end{tabular}

Tests of significance are far below the standard alpha 0.05 precisely at the level 0.000 for symbolic role, liaison, monitor, router information, spokesperson, entrepreneur and resource allocation. At the 0.020 level for the interrupt handling role and 0.002 for the negotiator role. this results support the hypothesis 2 of this research that there is a positive and significant correlation between the understanding of the role from the leaders of the branch with the central leadership expectations role to the work performance achievement of the branch leaders.

\section{Discussion}

From the results above, it shows that there are significant differences between expectations and understanding role. This can be seen from the results of $H 1$, it proves them in ten leadership roles according to Mintzberg. These results indicate that the transmission of company expectations about the importance of the leadership roles which is represented by central leaders in the middle level management, has not been well realized. The existence of the significant differsity is as the evidence that there is still a lack of socialization that was carried out by the central leadership toward the leadership roles and the different perceptions of the middle-level management relates to the authority and responsibility that must be fulfilled. Therefore, there are differences perception in these roles implementation. The diversity will greatly influence toward understanding the roles. As expressed by Katz \& Khan (1978), (2006), that the failure in communicating the importance of roles in organizations will cause the diversity in understanding the role. What stakeholders understand about the role do not match to what the giver expects. This research is in line with the research which was conducted by Hastuti (1987). Understanding someone's role will also have a large influence to the person who is carrying out their duties properly and correctly. This term will have an effect to the work performance that they can achieve. This is seen well in $\mathrm{H} 2$, it proves that there is a strong connection between the understanding the leadership and the 


\section{Jurnal Mirai Management Terakreditasi Nasional}

e-ISSN : 2597 - 4084, Volume 4 No.1 2019

Available Online at: https://journal.stieamkop.ac.id/index.php/mirai

performance, according to Mintzberg. The truth tells that to understand the role, influences the work performance. It is in line to the research conducted by Soemanegara (2006); and Siahaan (2011),

\section{Management Implications}

The diversity of different perceptions between leaders and subordinates will cause obstacles for the organization to achieve the goals which have been set up in the vision and mission. When this happens, then the organization will be busy to align and to improve the internal resources that will reduce the portion of management in handling strategic issues that are important to the whole organization. The problem is especially in the leadership context, it will greatly weaken the organization, considering that the leadership is one of the important pillars of the organization in achieving goals (Armstrong \& Murlis, 2004) (Hurduzeu, 2015), Hidayat \& Latief (2018)

\section{Implications of Theory}

The results of this study can be as the great input in developing the management science, especially in terms to align the understanding among components of the organization in viewing organizational goals together. Agreemen and disagreement may become something that is very vital for the organization, and it also can be a part of developing topics for further research.

\section{CONCLUSION}

The presence of individuals in the organization can not be separated from the role to which it aspires. Environmental background, thoughts, personal understanding and expectations of each individual becomes a critical factor for companies that seek to harmonize understanding between components of the organization, in a collective value of which is expected to translate into individual roles within the company.

Proper understanding of the role, will provide assurance to the company so the company plans that require the support of human resources, will run in its place. Vice versa disagreement on the role would lead to the company's plans do not go as expected. Then it is clear here that the implications of the understanding of the role were able to show a person's work performance.

\section{REFERENCES :}

Altamony, H., \& Gharaibeh, A. (2017). The role of academic researcher to Mintzberg's managerial roles. International Journal of Business Management and Economic Research, 8(2), 920-925.

Andri Setiawan \& M.Djudi Mukzam. 2017. Analisis Peran kepemimpinan Dalam meningkatkan Komitmen Organisasi karyawan (Studi Kasus Pada PT.Bank 


\section{Jurnal Mirai Management Terakreditasi Nasional}

e-ISSN : 2597 - 4084, Volume 4 No.1 2019

Available Online at: https://journal.stieamkop.ac.id/index.php/mirai

Rakyat Indonesia (Persero) Kantor cabang Malang Kawi) Jurnal Administrasi Bisnis (JAB) Vol 50 No 6 September 2017.

Feirong Yuan \& Richard W.Woodman. 2017. Innovative Behaviour In The Workplace : The Role of performance and Image outcome Expectation. Academy of Management Journal Vol 53 No 2. https://doi.org/10.5465/amj.2010.49388995.

Haneberg.L. 2005. Build Midle Management Capacity Consulting to Management Vol 16 No 1. 37.

Jones Gabrielsson Morten Huse \& Alesandro Minicilly. 2007. Understanding The Leadership Role of The Board Chairperson Trough A Team production Approach. International Journal Of Leadership Studies. Vol 3 Iss 1. 2007 Pp 21-29 Schol Of Global Leadership \& Entrepreneurship. Regent University.

Katz, Daniel \& Kahn, Robert L. 2006. The Social Psychology of Organizations. At Becker \& Neuhauser The Efficient Organizations.New York. Elsevier.

Katz, Daniel dan Robert Kahn 1978.The Social Psychology of Organization,2nd Edition Wiley, New York.

Kinicki. Angelo dan Robert. Kreitner. 2003. Perilaku Organisasi.Jakarta : Salemba Empat

Kumar, P. (2015). An analytical study on mintzberg's framework: Managerial roles. International Journal of Research in Management \& Business Studies, 2(3), 12-19.

Marichal.K \& Segers, 2012. Leading From Midle The journy From Midle Management to Midle Leadership. White Papaer Antwerp Management School.

Mintzbert Henry., 1989. Inside Our Strange World of Organizations, fourth Edition, McGill University

Nadja Korpela. 2014. The Midle Manager Role A. Case Study Of Expectation Norm Behaviour and Conflict Within The Role. Departement of Entrepreneurship Management and Organization. Hanken School Of Economic. Helsinki.

Oliveira, J. D., Escrivao Filho, E., Nagano, M. S., \& Ferraudo, A. S. (2015). Managerial styles of small business owners: a study based on the organizational life cycle and on concepts concerning managers' functions and roles. Rbgn-revista Brasileira De Gestao De Negocios, 1279-1299. 


\section{Jurnal Mirai Management Terakreditasi Nasional}

e-ISSN : 2597 - 4084, Volume 4 No.1 2019

Available Online at: https://journal.stieamkop.ac.id/index.php/mirai

Pankaj Kumar Prabhjot Kaur \& R.K Kalra. 2013. Role Expectation Role Perseption and Role Performance Of Extention Personal. American International Journal of Research and Humanities Art and Social Sciences.

Porter, Lyman W dan E.Lawler. 1968. Managerial attitude and Performance. Homewood.Richard D.Irwin, Inc.

Saah, P. (2017). Exploring Mintzberg's managerial roles of academic leaders at a selected higher education institution in South Africa (Doctoral dissertation, North-West University (South Africa), Mafikeng Campus).

Sanghi. S. 2011. Human Resource Behavior Pp 138297 MaC Millan Publisher India Ltd Delhi

Siahaan, B. Z. (2011). Pengaruh Kemampuan Kerja, Persepsi Peran dan Motivasi Kerja terhadap Kinerja Pegawai Administrasi Universitas Negeri Jakarta. Jurnal manajemen pendidikan, 2(1), 48-57

Soemanagara, R. D. (2006). PERSEPSI PERAN, KONSISTENSI PERAN, DAN KINERJA. Jurnal IImu Administrasi: Media Pengembangan IImu dan Praktek Administrasi, 3(4), 02.

Rosally, C. (2015). Pengaruh konflik peran, ketidakjelasan peran, dan komitmen organisasi terhadap kinerja auditor. Business Accounting Review, 3(2), 31-40.

Ugur Ozcan. 2016. How Expectation Affect Performance (Empowerment in Management) Https://www.linkedin.com Downloaded at Juli 11. 2018

Zaraket, W. S. Mintzberg Management Folklore. In BOOK OF ABSTRACTS (p. 33). 